\title{
Efek Pemberian Ekstrak Etanol Daun Mimba (Azadirachta indica A. Juss.) terhadap Struktur Ren Tikus Putih (Rattus norvegicus L.) yang Diberi Pakan Tinggi Lemak
}

\section{The Effects of Ethanol Extract of Neem Leaves (Azadirachta indica A. Juss.) on the Kidney Structure of White Rat (Rattus norvegicus L.) Fed with a High-Fat Diet}

\author{
Winda Arini $^{1 *}$, Sri Isdadiyanto ${ }^{2}$, Agung Janika Sitasiwi ${ }^{3}$ \\ ${ }^{1}$ Mahasiswa Program Studi Biologi, Departemen Biologi, Fakultas Sains dan Matematika, \\ Universitas Diponegoro \\ ${ }^{2}$ Departemen Biologi, Fakultas Sains dan Matematika, Universitas Diponegoro \\ Jl. Prof. Soedarto, SH. Tembalang-Semarang 50275 \\ *Email: windaarini1999@gmail.com \\ Corresponding author: Sri Isdadiyanto. Email : isdadiyanto@yahoo.com
}

\begin{abstract}
ABSTRAK
Daun mimba mengandung senyawa bioaktif diantaranya terpenoid, alkaloid dan flavonoid yang diduga memiliki efek dalam menurunkan kolesterol. Penelitian bertujuan untuk menguji efek pemberian ekstrak etanol daun mimba (Azadirachta indica A. Juss.) terhadap struktur ren tikus putih (Rattus norvegicus L.) yang diberi pakan tinggi lemak. Penelitian menggunakan Rancangan Acak Lengkap yang dibagi menjadi 6 kelompok dan 4 kali pengulangan, yaitu P0 (kontrol negatif), P1 (kontrol positif), P2 (simvastatin 8 mg), P3, P4 dan P5 (uji dosis ekstrak etanol daun mimba 75, 100 dan $125 \mathrm{mg}$ ). Variabel yang diamati yaitu bobot ginjal, diameter glomerulus, diameter kapsula Bowman dan tebal ruang Bowman. Hasil penelitian menunjukan tidak terdapat pengaruh bermakna $(p>0,05)$ dari pemberian ekstrak etanol daun mimba terhadap bobot ginjal, diameter glomerulus, diameter kapsula Bowman dan tebal ruang Bowman pada ginjal tikus yang diberi pakan tinggi lemak. Kesimpulan penelitian ini yaitu ekstrak etanol daun mimba mampu memperbaiki struktur ginjal tikus hiperlipidemia.
\end{abstract}

Kata kunci : pakan tinggi lemak, daun mimba, diameter glomerulus, diameter kapsula Bowman

\begin{abstract}
Neem leaves contain bioactive compounds including terpenoids, alkaloids and flavonoids which are thought to have effects in decreasing the concentration of cholesterol. This study aimed to examine the effect of ethanol extract of neem leaf (Azadirachta indica A. Juss.) on the kidney structure of white rat (Rattus norvegicus L.) fed with a high-fat diet. The study used a Completely Randomized Design which were divided into 6 groups and 4 repetitions, namely P0 (the negative control), P1 (the positive control), P2 (simvastatin $8 \mathrm{mg}$ ), P3, P4 and P5 (a test dose of ethanol extract of neem leaf at 75, 100 and $125 \mathrm{mg}$ ). The variables observed were kidney weight, glomerular diameter, Bowman capsule diameter and thickness of Bowman space. The results showed no significant effect ( $p>0.05$ ) from the administration of ethanol extract of neem leaf on the kidney weight, the glomerular diameter, the Bowman capsule diameter and the thickness of Bowman space in the kidney of rat fed a high-fat diet. This research concluded that the ethanol extract of neem leaf can repair the structure of the hyperlipidemic rat kidney.
\end{abstract}

Keywords : a high-fat diet, neem leaves, glomerular diameter, Bowman capsule diameter 


\section{PENDAHULUAN}

Pakan tinggi lemak adalah pakan yang mengandung lemak dengan konsentrasi tinggi (Setiawati dkk., 2016). Kandungan kolesterol yang relatif tinggi dapat ditemukan dalam kuning telur dibandingkan dengan beberapa makanan lain karena kuning telur mengandung lebih dari dua per tiga asupan harian kolesterol (300 mg) yang direkomendasikan (Onyenweaku et al., 2018). Minyak jelantah mengandung banyak radikal bebas akibat peroksidasi lipid. Konsumsi minyak jelantah secara berulang menyebabkan kerusakan berbagai organ tubuh seperti pembuluh darah, jantung, hati dan ginjal akibat terjadinya penumpukan lemak (Muhartono dkk., 2018). Konsumsi makanan yang digoreng dengan minyak pada suhu tinggi (deep fried) dalam jangka waktu yang lama akan menghasilkan peroksidasi lipid yang menginduksi terjadinya disfungsi endotel (Hanung dkk., 2019).

Pakan tinggi lemak dapat mengakibatkan hiperinsulinemia yang menyebabkan peningkatan dalam penyimpanan nutrien sehingga obesitas dapat terjadi lebih cepat. Asupan lemak yang tinggi dapat menyebabkan akumulasi dalam tubuh, dan apabila penumpukan lemak terjadi di organ ginjal maka dapat menyebabkan resiko gagal ginjal kronis dan hipertensi. Kelebihan lemak di dalam tubuh ditimbun dalam jaringan subkutan, di sekitar organ tubuh dan terkadang terjadi perluasan hingga ke dalam jaringan penyusun organ (Misnadierly, 2007). Berdasarkan berbagai penelitian yang telah dilakukan, diketahui bahwa penyakit gagal ginjal kronis dapat disebabkan oleh akumulasi lemak pada jaringan non adiposa. Penimbunan lemak pada jaringan dalam ginjal dapat menyebabkan perubahan struktur glomerulus, perubahan fisiologi ginjal, nekrosis tubulus ginjal, penurunan berat badan dan organ, terjadi peradangan (inflamasi) dan degenerasi (Eghziaber et al., 2013).

Mimba (Azadirachta indica A. Juss.) merupakan tanaman yang telah dikenal sebagai tanaman obat. Mimba dapat digunakan sebagai obat aterosklerosis dan antikolesterol (Seo \& Wuryandari, 2017). Supriyanto dkk. (2017) menyatakan bahwa ekstrak daun mimba memiliki aktivitas antioksidan yang kuat. Seo \& Wuryandari (2017) menyatakan bahwa kandungan senyawa flavonoid, terpenoid dan alkaloid yang ada pada daun mimba mampu menurunkan kadar kolesterol dalam tubuh atau disebut dengan anti kolesterol. Tandi dkk. (2017) dalam hasil penelitiannya menyatakan bahwa senyawa flavonoid yang terkandung di dalam tanaman mimba dapat memberikan efek potensial sebagai agen diuretikum sehingga mampu meningkatkan laju filtrasi glomerulus. Peningkatan laju filtrasi glomerulus menyebabkan zat nefrotoksik yang masuk ke dalam ginjal akan dikeluarkan dengan cepat akibat aktivitas urinasi yang meningkat. Penelitian ini perlu dilakukan untuk membuktikan efek pemberian ekstrak etanol daun mimba (Azadirachta indica A. Juss.) dalam mempertahankan struktur ren tikus putih (Rattus norvegicus L.) yang hiperkolesterol.

\section{METODE PENELITIAN}

\section{Hewan Uji}

Hewan uji yang digunakan dalam penelitian ini adalah tikus putih jantan (Rattus norvegicus L.) Strain Wistar berumur dua bulan sebanyak 24 ekor dengan bobot berkisar 100-170 g. Tikus diaklimasi selama tujuh hari dalam kondisi laboratorium yang terkontrol dengan menempatkan 1 tikus pada setiap kandang pemeliharaan dengan kisaran suhu $20-24^{\circ} \mathrm{C}$ dan kelembaban relatif $45-65 \%$. Pakan standar dan air minum diberikan secara ad libitum.

\section{Pembuatan Pakan Tinggi Lemak}

Pakan tinggi lemak berupa pakan komersial yang dicampur dengan minyak jelantah dan kuning telur bebek. Minyak jelantah diperoleh dari minyak goreng kemasan satu liter untuk menggoreng tahu putih seberat $450 \mathrm{~g}$ selama \pm 10 menit dengan suhu $150-165^{\circ} \mathrm{C}$ menggunakan teknik deep fat frying (Muhartono dkk., 2018) 
sebanyak sembilan kali penggorengan (Hanung dkk., 2019). Pakan tinggi lemak pada penelitian ini dibuat dengan cara setiap 30g pakan komersial ditambahkan dengan $3 \mathrm{ml}$ minyak jelantah, lalu dihomogenkan sampai merata.

\section{Pembuatan Ekstrak Etanol Daun Mimba}

Daun mimba diperoleh dari area sekitar kampus Fakultas Sains dan Matematika Universitas Diponegoro. Selanjutnya daun dikeringkan di dalam oven dengan suhu $\pm 45-50^{\circ} \mathrm{C}$. Daun yang telah disusun lalu dibalik setiap hari sampai kering secara merata (Hasana dkk., 2016). Daun dapat dinyatakan kering apabila beratnya mencapai konstan dengan syarat menimbang sebanyak dua kali penimbangan berturut-turut. Daun yang sudah kering dihancurkan menggunakan tangan secara mekanik sampai terbentuk serbuk. Ekstraksi daun mimba dilaksanakan di Laboratorium Kimia Universitas Negeri Semarang dengan metode maserasi menggunakan etanol 70\%, lalu dievaporasi hingga ekstrak berbentuk serbuk.

\section{Perlakuan Hewan Uji}

Tikus dibagi dalam 6 kelompok perlakuan, yaitu P0 (kelompok kontrol negatif); P1 (kelompok kontrol positif, diberi pakan tinggi lemak); P2 (diberi pakan tinggi lemak + $8 \mathrm{mg} / 200 \mathrm{gBB}$ simvastatin); P3, P4 dan P5 (diberi pakan tinggi lemak dan uji dosis ekstrak etanol daun mimba 75;100 dan $125 \mathrm{mg} / 200 \mathrm{gBB}$ ekstrak etanol daun mimba). Ekstrak etanol daun mimba dan simvastatin diberikan setiap hari pada sore hari. Pakan tinggi lemak berupa campuran pakan komersial dan minyak jelantah diberikan setiap hari pada pagi hari, sedangkan kuning telur bebek diberikan dua hari sekali pada pagi hari. Perlakuan diberikan selama 44 hari. Bobot badan tikus putih ditimbang setiap 1 minggu sekali, sedangkan konsumsi pakan dan minum diukur setiap hari.

\section{Koleksi Sampel}

Pembedahan dan pengambilan organ dilakukan setelah hewan uji dibius menggunakan kloroform. Diseksi dilakukan dengan memotong jaringan kulit anterior-inferior abdomen sehingga topografi terlihat dengan baik (Sari dkk., 2019). Selanjutnya organ ginjal diisolasi. Organ ginjal yang telah terambil selanjutnya ditimbang lalu dicuci dengan larutan garam fisiologis. Selanjutnya organ difiksasi dengan larutan BNF 10\%.

\section{Pembuatan dan Pewarnaan Preparat}

Preparat histologi ren dibuat dengan metode parafin dan fiksatif menggunakan larutan $10 \%$ BNF (Isdadiyanto, 2018) dengan ketebalan sayatan $5 \mu \mathrm{m}$, serta pewarnaan Hematoxylin dan Eosin (H\&E).

\section{Pengamatan Preparat}

Variabel yang diamati adalah bobot ginjal, diameter glomerulus, diameter kapsula Bowman dan tebal ruang Bowman (Fahrimal et al., 2016). Pengamatan dan pengukuran diameter glomerulus, diameter kapsula Bowman dan tebal ruang Bowman menggunakan fotomikrograf dengan perbesaran 200x. Setiap preparat diamati sebanyak lima bidang pandang. Setiap bidang pandang, dilakukan pengamatan sepuluh glomerulus. Diameter glomerulus yang didapatkan merupakan rata-rata dari pengukuran diameter setiap glomerulus secara tegak lurus bidang pengamatan (Nurasri dkk., 2018).

\section{Analisis Data}


Data yang diperoleh yaitu rata-rata bobot ginjal, diameter glomerulus, diameter kapsul Bowman dan tebal ruang Bowman dari kelompok kontrol dan kelompok perlakuan. Pengolahan data dilakukan dengan menggunakan program software SPSS 23.0. Data dianalisis dengan menggunakan uji ANOVA (analysis of variance) one way pada taraf kepercayaan $95 \%$.

\section{HASIL DAN PEMBAHASAN}

Hasil analisa statistik menunjukkan bahwa efek pemberian perlakuan ekstrak etanol daun mimba (Azadirachta indica A. Juss.) terhadap rerata diameter glomerulus, diameter kapsula Bowman, tebal ruang Bowman dan bobot ginjal tikus putih (Rattus norvegicus L.) yang diberi pakan tinggi lemak menunjukkan perbedaan tidak bermakna ( $\mathrm{p}>0.05$ ) antara kelompok kontrol negatif $(\mathrm{P} 0)$ dengan kelompok perlakuan. Hal ini disebabkan karena rerata diameter glomerulus, diameter kapsula Bowman, tebal ruang Bowman dan bobot ginjal kelompok perlakuan (P2, P3, P4 dan P5) mendekati rerata ukuran kelompok kontrol negatif.

Pengukuran diameter glomerulus, diperoleh rerata diameter glomerulus pada kelompok kontrol negatif (P0) dan kelompok perlakuan (P1, P2, P3, P4 dan P5) yaitu P0 (77.88 \pm 5.18$),$ P1 (80.53 \pm 2.78$),$ P2 (75.12 \pm 6.17$)$, P3 (70.75 \pm 1.89$)$, P4 (76.22 \pm 1.79$)$ dan P5 (76.93 \pm 4.77$)$. Hasil analisis statistik mengenai pengaruh pemberian ekstrak etanol daun mimba terhadap diameter glomerulus ginjal tikus yang diberi pakan tinggi lemak menunjukkan hasil yang berbeda tidak bermakna ( $p>0.05$ ). Hasil penelitian ini membuktikan bahwa pemberian ekstrak etanol daun mimba dosis $75 \mathrm{mg} / \mathrm{gBB}, 100 \mathrm{mg} / \mathrm{gBB}$ dan $125 \mathrm{mg} / \mathrm{gBB}$ dapat memperbaiki ukuran diameter glomerulus karena mendekati ukuran diameter glomerulus pada kelompok kontrol negatif (P0) dan kelompok perlakuan simvastatin (P2). Hasil penelitian ini sesuai dengan Rao et al. (2019) menyatakan bahwa pemberian ekstrak etanol daun mimba dengan dosis bertingkat dapat menurunkan kerusakan glomerulus pada ginjal tikus, hal ini disebabkan oleh kandungan flavonoid pada daun mimba. Senyawa flavonoid mempunyai aktivitas antioksidan yang meredam radikal bebas yang banyak dihasilkan pada proses kerusakan glomerulus sehingga kerusakan lebih lanjut dapat dicegah dan menuju pemulihan.

Hasil analisis uji Analysis of Variance (ANOVA) one way diameter glomerulus, diameter kapsula Bowman, tebal ruang Bowman dan bobot ginjal antara kelompok kontrol dengan kelompok perlakuan, disajikan pada Tabel 4.1.

Tabel 4.1. Rerata diameter glomerulus, diameter kapsula Bowman, tebal ruang Bowman dan bobot ginjal yang diberi pakan tinggi lemak setelah pemberian ekstrak etanol daun mimba

\begin{tabular}{ccccc}
\hline Perlakuan & $\begin{array}{c}\text { Diameter } \\
\text { Glomerulus }(\mu \mathrm{m}) \\
\mathrm{X} \pm \mathrm{SD}\end{array}$ & $\begin{array}{c}\text { Variabel } \\
\text { Bowman }(\mu \mathrm{m}) \\
\mathrm{X} \pm \mathrm{SD}\end{array}$ & $\begin{array}{c}\text { Tebal ruang } \\
\text { Bowman }(\mu \mathrm{m}) \\
\mathrm{X} \pm \mathrm{SD}\end{array}$ & Bobot Ginjal $(\mathrm{g})$ \\
\hline P0 & $77.88 \pm 5.18$ & $90.42 \pm 8.91$ & $6.27 \pm 2.31$ & $\mathrm{X} \pm \mathrm{SD}$ \\
P1 & $80.53 \pm 2.78$ & $90.85 \pm 2.28$ & $5.16 \pm 0.52$ & $0.87 \pm 0.04$ \\
P2 & $75.12 \pm 6.17$ & $85.78 \pm 7.38$ & $4.84 \pm 0.87$ & $0.87 \pm 0.13$ \\
P3 & $70.75 \pm 1.89$ & $81.52 \pm 1.51$ & $5.39 \pm 0.21$ & $0.69 \pm 0.12$ \\
P4 & $76.22 \pm 1.79$ & $87.82 \pm 2.48$ & $5.69 \pm 0.38$ & $0.82 \pm 0.25$ \\
P5 & $76.93 \pm 4.77$ & $87.37 \pm 7.23$ & $5.22 \pm 1.72$ & $0.79 \pm 0.17$ \\
\hline
\end{tabular}

Keterangan: P0 (kelompok kontrol negatif yang diberi pakan standar), P1 (kelompok kontrol positif yang diberi pakan tinggi lemak dan kuning telur bebek per oral 2,5 ml/200gBB), P2 (kelompok perlakuan yang diberi pakan tinggi lemak dan kuning telur bebek per oral $2,5 \mathrm{ml} / 200 \mathrm{gBB}+8 \mathrm{mg} / \mathrm{gBB}$ simvastatin dalam $1 \mathrm{ml}$ akuades), P3 (kelompok perlakuan yang diberi pakan tinggi lemak dan kuning telur bebek per oral 2,5 ml/200gBB + 
$75 \mathrm{mg} / \mathrm{gBB}$ ekstrak etanol daun A. Indica A. Juss. dalam $1 \mathrm{ml}$ akuades), P4 (kelompok perlakuan yang diberi pakan tinggi lemak dan kuning telur bebek per oral $2,5 \mathrm{ml} / 200 \mathrm{gBB}+100 \mathrm{mg} / \mathrm{gBB}$ ekstrak etanol daun $A$. Indica A. Juss. dalam $1 \mathrm{ml}$ akuades) dan P5 (kelompok perlakuan yang diberi pakan tinggi lemak dan kuning telur bebek per oral 2,5 ml/200gBB $+125 \mathrm{mg} / \mathrm{gBB}$ ekstrak etanol daun A. Indica A. Juss. dalam $1 \mathrm{ml}$ akuades

Pengukuran diameter kapsula Bowman, diperoleh rerata diameter kapsula Bowman pada kelompok kontrol negatif (P0) dan kelompok perlakuan (P1, P2, P3, P4 dan P5) yaitu P0 (90.42 \pm 8.91$)$, P1 (90.85 \pm 2.28$)$, P2 (85.78 \pm 7.38$),$ P3 (81.52 \pm 1.51$),$ P4 (87.82 \pm 2.48$)$ dan P5 (87.37 \pm 7.23$)$. Hasil analisis statistik menunjukkan bahwa pemberian ekstrak etanol daun mimba memberikan hasil yang berbeda tidak bermakna $(p>0.05)$ terhadap diameter kapsula Bowman. Hal ini membuktikan bahwa pemberian ekstrak etanol daun mimba dosis 75 $\mathrm{mg} / \mathrm{gBB}, 100 \mathrm{mg} / \mathrm{gBB}$ dan $125 \mathrm{mg} / \mathrm{gBB}$ selama 45 hari dapat memperbaiki ukuran diameter kapsula Bowman sehingga mendekati ukuran diameter kapsula Bowman kelompok kontrol negatif (P0) dan kelompok perlakuan simvastatin (P2). Hasil penelitian ini sesuai dengan Septiva (2019) bahwa penurunan diameter kapsula Bowman disebabkan oleh jaringan pada sel-sel epitel penyusun membran kapsula Bowman mengalami perbaikan seiring dengan pemberian dosis ekstrak etanol daun mimba.

Pengukuran tebal ruang Bowman, diperoleh rerata tebal ruang Bowman pada kelompok kontrol negatif (P0) dan kelompok perlakuan (P1, P2, P3, P4 dan P5) yaitu P0 (6.27 \pm 2.31$)$, P1 (5.16 \pm 0.52$),$ P2 (4.84 \pm 0.87$),$ P3 (5.39 \pm 0.21$),$ P4 (5.69 \pm 0.38$)$ dan P5 (5.22 \pm 1.72$)$. Hasil analisis statistik menunjukkan bahwa pemberian ekstrak etanol daun mimba memberikan hasil yang berbeda tidak bermakna ( $p>0.05)$ pada variabel tebal ruang Bowman. Hasil tersebut membuktikan bahwa pemberian ekstrak etanol daun mimba dengan dosis $75 \mathrm{mg} / \mathrm{gBB}, 100 \mathrm{mg} / \mathrm{gBB}$ dan $125 \mathrm{mg} / \mathrm{gBB}$ diduga mampu memperbaiki ukuran tebal ruang bowman ginjal tikus jantan yang diberi pakan tinggi lemak. Hasil penelitian ini sesuai dengan Septiva (2019) bahwa ekstrak etanol daun mimba tidak menimbulkan kerusakan dan mampu memperbaiki ruang Bowman ginjal.

Rerata bobot ginjal tikus dari masing-masing kelompok perlakuan, yaitu P0 $(0.87 \pm 0.04)$, P1 $(0.87 \pm 0.13), \mathrm{P} 2(0.89 \pm 0.12), \mathrm{P} 3(0.65 \pm 0.18), \mathrm{P} 4(0.82 \pm 0.25)$ dan P5 $(0.79 \pm 0.17)$. Hasil analisis statistik menunjukkan bahwa pemberian ekstrak etanol daun mimba menunjukkan hasil yang berbeda tidak bermakna (p>0.05) pada variabel bobot ginjal antara kelompok kontrol negatif (P0) dengan kelompok perlakuan (P1, P2, P3, P4, P5). Hal ini diduga karena pemberian ekstrak etanol daun mimba dengan dosis $75 \mathrm{mg} / \mathrm{gBB}, 100 \mathrm{mg} / \mathrm{gBB}$ dan $125 \mathrm{mg} / \mathrm{gBB}$ mampu menekan efek kerusakan yang disebabkan oleh hiperkolesterol sehingga tidak menyebabkan perubahan bobot ginjal. Wresdiyati dkk. (2011) menyatakan bahwa ekstrak etanol daun mimba mampu mempengaruhi atau menekan efek buruk dari hiperkolesterol. Radikal bebas yang meningkat pada kondisi hiperkolesterolemia dapat menyerang makromolekul sel sehingga dapat menyebabkan nekrosis dan degenerasi sel. 

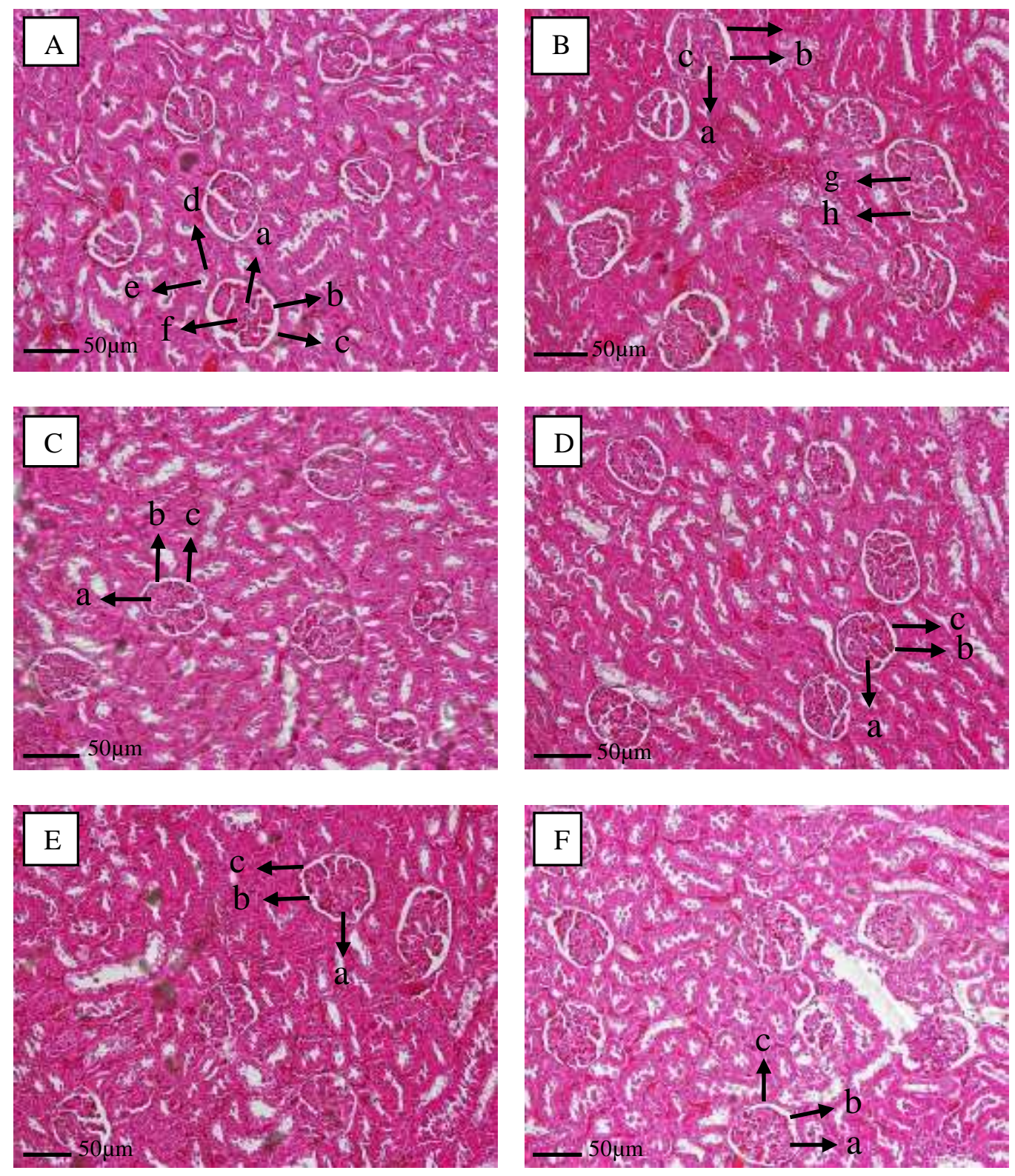

Gambar 4.1. Mikroanatomi ginjal tikus (pewarnaan H\&E, perbesaran 200x), (A) Kelompok kontrol negatif, (B) Klompok kontrol positif, (C) Kelompok perlakuan simvastatin dosis $8 \mathrm{mg} / \mathrm{gBB}$, (D) Kelompok perlakuan ekstrak daun mimba dosis $75 \mathrm{mg} / \mathrm{gBB}$, (E) Kelompok perlakuan ekstrak daun mimba dosis $100 \mathrm{mg} / \mathrm{gBB}$, (F) Kelompok perlakuanekstrak daun mimba dosis $125 \mathrm{mg} / \mathrm{gBB}$. Keterangan: (a) glomerulus, (b) tebal ruang Bowman, (c) kapsula Bowman, (d) tubulus, (e) lumen, (f) sel podosit, (g) pembesaran glomerulus, (h) penyempitan ruang Bowman

Gambar sediaan histologis A (kelompok kontrol negatif) terlihat korpus renalis dan tubulus ginjal dalam keadaan normal. Glomerulus tampak normal, kapsula Bowman tersusun atas lapisan viseralis dan lapisan parietal, membentuk ruang Bowman. Hasil penelitian ini didukung oleh Windhartono dkk. (2013) bahwa struktur jaringan ginjal normal terlihat sel-selnya tampak normal. Glomerulus tampak sebagai kumpulan sel-sel yang rapat dan berbentuk menyerupai lingkaran. Tubulus kontortus proksimal dan distal pada kondisi normal terlihat sel tidak mengalami pembengkakan, lumen tubulus jelas dan inti sel bulat.

Gambar sediaan histologis B (kelompok kontrol positif) menunjukkan ukuran diameter glomerulus yang lebih besar dibandingkan dengan kelompok kontrol negatif dan kelompok perlakuan, namun masih dalam 
ukuran yang relatif sama. Hal ini disebabkan karena pembengkakan dan perubahan pada sel glomerulus sebagai bentuk dari adaptasi seluler seiring pakan tinggi lemak yang diberikan. Hal ini didukung oleh Yao et al. (2015) bahwa pembesaran glomerulus disebabkan oleh meningkatnya reaksi radang yang terjadi akibat stres oksidatif radikal bebas dan hiperfiltrasi glomerulus pada kondisi hiperlipidemia.

Gambar sayatan organ histologis C (kelompok perlakuan simvastatin) dapat terlihat bahwa sayatan histologis ginjalnya memiliki kesamaan dengan histologis ginjal normal. Hal ini membuktikan bahwa pemberian obat simvastatin dapat mencegah kerusakan ginjal pada tikus hiperlipidemia. Simvastatin yang digunakan sebagai obat antikolesterol dalam penelitian ini adalah salah satu obat dari golongan statin yang dapat menurunkan kadar trigliserida. Hal ini sesuai dengan penelitian Kusuma dkk. (2016) yang menyatakan bahwa simvastatin mempunyai mekanisme antikolesterol dengan menghambat secara kompetitif enzim HMG-KoA reduktase yang berfungsi sebagai katalis dalam pembentukan kolesterol. Penghambatan terhadap HMG-KoA reduktase dapat menyebabkan penurunan sintesis kolesterol.

Gambar sediaan histologis D (kelompok perlakuan ekstrak etanol daun mimba dosis $75 \mathrm{mg} / \mathrm{gBB}$ ) terlihat bahwa sayatan histologis ginjal tidak berbeda dengan struktur histologis ginjal normal. Ukuran diameter glomerulus, kapsula Bowman dan tebal ruang Bowman lebih kecil dibandingkan dengan ukuran kelompok kontrol negatif, namun dalam ukuran yang relatif sama. Hal ini dapat disebabkan karena pemberian dosis yang masih rendah, akan tetapi dosis tersebut dapat memperbaiki struktur ginjal tikus hiperlipidemia. Ekstrak etanol daun mimba dosis $75 \mathrm{mg} / \mathrm{gBB}$ membuktikan dapat memperbaiki struktur ginjal tikus hiperlipidemia.

Gambar sediaan histologis E (kelompok perlakuan ekstrak etanol daun mimba dosis $100 \mathrm{mg} / \mathrm{gBB}$ ) terlihat struktur ginjal tikus yang tidak berbeda dengan struktur ginjal tikus kelompok kontrol negatif. Ukuran diameter glomerulus, diameter kapsula Bowman dan tebal ruang Bowman lebih kecil dibandingkan dengan ukuran kelompok kontrol negatif, namun dalam ukuran yang relatif sama. Hal ini membuktikan bahwa pemberian ekstrak etanol daun mimba dosis $100 \mathrm{mg} / \mathrm{gBB}$ mampu memperbaiki struktur ginjal tikus hiperlipidemia.

Gambar sediaan histologis F (ekstrak etanol daun mimba dosis $125 \mathrm{mg} / \mathrm{gBB}$ ) menunjukkan bahwa sediaan histologis ginjal tikus tidak berbeda dengan struktur histologis ginjal tikus kelompok kontrol negatif. Ukuran diameter glomerulus, kapsula Bowman dan tebal ruang Bowman lebih kecil dibandingkan ukuran kelompok kontrol negatif, tetapi dalam ukuran yang relatif sama. Hal ini diduga karena pemberian dosis yang cukup tinggi, tetapi dosis tersebut dapat memperbaiki morfologi ginjal tikus hiperlipidemia. Ekstrak etanol daun mimba dosis $125 \mathrm{mg} / \mathrm{gBB}$ dapat memperbaiki struktur histologis ginjal tikus hiperlipidemia.

Hasil penelitian ini menunjukkan bahwa efek pemberian ekstrak etanol daun mimba dengan dosis berbeda mampu memperbaiki struktur ginjal tikus putih jantan yang hiperlipidemia. Kondisi hiperlipidemia pada tikus diinduksi dengan pemberian pakan tinggi lemak selama 45 hari. Kuning telur bebek juga diberikan setiap dua hari sekali per oral 2,5 ml/200gBB dengan cara disonde. Pola makan yang cenderung tinggi lemak jenuh dapat menyebabkan kolesterol dalam jumlah berlebihan dalam darah. Wikanta (2003), menyatakan bahwa kuning telur bebek diberikan setiap dua hari sekali per oral 2,5 ml/200gBB yang mengandung 2,8 $\mathrm{g}$ kuning telur dan bertujuan untuk meningkatkan kadar kolesterol secara eksogen.

Pemberian ekstrak etanol daun mimba pada penelitian ini diberikan secara oral dengan jalur masuk ke dalam tubuh melalui traktus digestivus menuju organ tubuh lain yakni ginjal melalui serangkaian proses. Kester (2012) menyatakan bahwa zat asing sebagai obat yang masuk ke dalam tubuh melalui beberapa tahap yaitu absorbsi, metabolisme, distribusi dan eliminasi.

Daun mimba mengandung antioksidan kuat yang mampu menekan stres oksidatif yang terjadi akibat hiperkolesterol. Hasil penelitian ini sesuai dengan Pandey (2014) menyatakan bahwa ekstrak daun mimba mengandung flavonoid yang bertindak sebagai antioksidan dan berfungsi untuk memberikan perlindungan terhadap radikal bebas yang merusak sel dan jaringan. Shareef \& Akhtar (2018) menyatakan bahwa daun mimba adalah sumber antioksidan yang tinggi. Antioksidan menstabilkan reactive oxygen species sebelum menyerang seluruh sistem biologis. Antioksidan mengaktifkan enzim oksidatif untuk mencegah kerusakan akibat reactive oxygen species dan radikal bebas. 


\section{KESIMPULAN}

Hasil dari penelitian ini menunjukkan bahwa pemberian ekstrak etanol daun mimba dengan dosis 75 $\mathrm{mg} / \mathrm{gBB}, 100 \mathrm{mg} / \mathrm{gBB}$ dan $125 \mathrm{mg} / \mathrm{gBB}$ terhadap struktur ginjal tikus putih jantan yang diberi pakan tinggi lemak memberikan efek berbeda tidak bermakna terhadap diameter glomerulus, diameter kapsula Bowman dan tebal ruang Bowman, sehingga dapat disimpulkan bahwa ekstrak etanol daun mimba mampu memperbaiki struktur ginjal tikus yang hiperlipidemia.

\section{DAFTAR PUSTAKA}

Eghziaber, F.G., Pascaline, M. A., Koppe, L., Pelletier, C. C., Kalbacher, E., Denis, F. \& Soulage, C. O. 2013. Ectopic Lipid Accumulation: A Potential cause for Metabolic Disturbances and A Contributor to the Alteration of Kidney Function. Biochemical. 95: 1971-1979.

Fahrimal, Y., Rahmiwati. \& Aliza, D. 2016. Gambaran Histologi Ginjal Tikus Putih (Rattus norvegicus L.) Jantan yang Diinfeksikan Trypanosoma evansi dan Diberi Ekstrak Daun Sernai (Wedelia biflora). Jurnal Medika Veterinaria. 10(2): 166-170.

Hanung, A., Saktini, F. \& Gumay, A. R. 2019. Pengaruh Frekuensi Penggorengan Minyak Jelantah terhadap Diameter dan Gambaran Histologi Lumen Aorta Tikus Wistar (Rattus norvegicus L.). JKD (Jurnal Kedokteran Diponegoro). 8(1): 26-37.

Hasana, A. N., Sitasiwi, A. J. \& Isdadiyanto, S. 2016. Hepatosomatik Indeks dan Diameter Hepatosit Mencit (Mus musculus L.) Betina setelah Paparan Ekstrak Etanol Daun Mimba (Azadirachta indica Juss.). Jurnal Pro-Life. 6(1): 1-12.

Isdadiyanto, S. 2018. Pengaruh Waktu Fermentasi Teh Kombucha Kadar 50\% terhadap Tebal Dinding dan Diameter Lumen Arteria Koronaria Tikus Putih. Bioma. 20(2): 140-145.

Kester, M. 2012. Elsevier's Integrated Review Pharmacology $2^{\text {nd }}$ Edition. Elsevier, Philadelphia.

Kusuma, A. M., Asarina, Y., Rahmawati, Y. I. \& Susanti. 2016. Efek Ekstrak Bawang Dayak (Eleutherine palmifolia (L.) Merr) dan Ubi Ungu (Ipomoea batatas L.) terhadap Penurunan Kadar Kolesterol dan Trigliserida Darah pada Tikus Jantan. Jurnal Kefarmasian Indonesia. 6(2): 108-116.

Misnadierly. 2007. Obesitas sebagai Faktor Resiko Berbagai Penyakit. Jakarta: Pustaka Obor Populer.

Muhartono., Yudistira, M. A., Putri, N. T., Sari, T. N. \& Oktafany. 2018. Minyak Jelantah Menyebabkan Kerusakan pada Arteri Koronaria, Miokardium, dan Hepar Tikus Putih (Rattus norvegicus L.) Jantan Galur Sprague dawley. JK Unila. 2(2): 129-135.

Nurasri, R., Yuniwarti, E. Y. W. \& Djaelani, M. A. 2018. Pengaruh Pemberian Virgin Coconut Oil (VCO) dan Olive Oil terhadap Mikroanatomi Ren Tikus Putih (Rattus norvegicus L.). Bioma. 20(2): 133-139.

Onyenweaku, E. O., Ene-Obong, H. N., Inyang, M. I. \& Williams, I. O. 2018. Cholesterol and Fatty Acid Profiles of Some Bird Egg Varieties: Possible Health Implications. Asian Food Science Journal. 3(4): $1-9$.

Pandey, G., Verma, K. \& Singh, M. 2014. Evaluation of Phytochemical, Antibacterial and Free Radical Scavenging Properties of Azadirachta indica (Neem) Leaves. International Journal of Pharmacy and Pharmaceutical Sciences. 6(2): 444-447. 
Rao, P. S., Subramanayam, G. \& Sridhar, P. R. 2019. Quercetin 3-Galactoside from Azadirachta indica. Journal of Advances in Molecular Biology. 3(1): 1-8.

Sari, A.K., Adi, S. \& Saichudin. 2019. Efek Latihan Aerobik Interval dan Continuous terhadap Kadar SGOT dan SGPT pada Tikus Diabetes Induksi Streptozotocin. Jurnal Bio Komplementer Medicine. 6(1): 1-11.

Seo, A. L. \& Wuryandari, W. 2017. Neem (Azadirachta indica A. Juss.) Leaf Brew as a Cholesterol Lowering Potion for Rats (Rattus norvegicus L.). Scientific Papers. Academy of Pharmacy of Putra Indonesia Malang. 1-10.

Septiva, E. B., Sitasiwi, A. J. \& Isdadiyanto, S. 2019. Struktur Mikroanatomi Ginjal Mencit (Mus musculus L.) Betina setelah Paparan Ekstrak Etanol Daun Mimba (Azadirachta indica A. Juss). Jurnal Pro-Life. 6(2): 180-190.

Setiawati, T., Atmomarsono, U. \& Dwiloka, B. 2016. Kadar Lemak dan Profil Asam Lemak Jenuh, Asam Lemak Tak Jenuh Daging Ayam Broiler dengan Pemberian Pakan Mengandung Tepung Daun Kayambang (Salvinia molesta). Jurnal Teknologi hasil Pertanian. 9(2): 1-8.

Shareef, M. \& Akhtar, M. S. 2018. Neem (Azadirachta indica) and its Potential for Safeguarding Health, Prevention and Treatment of Diseases. Matrix Science Medica (MSM). 2(1): 04-08.

Tandi, J., Roem, M. \& Yuliet. 2017. Efek Nefroprotekti Kombinasi Ekstrak Daun Gedi Merah dan Daun Kumis Kucing pada Tikus Induksi Etilen Glikol. J. Trop. Pharm. Chem. 4(1): 27-34.

Wikanta, T., Nasution, R. \& Rahayu, L.2003. Pengaruh Pemberian Alginat terhadap Penurunan Kadar Kolesterol Darah dan Bobot Badan Tikus. Jurnal Penelitian Perikanan Indonesia. 9(5).

Windhartono, W., Kamal, Z., Sasmito, E. 2013. Pengaruh Infusa Wortel (Daucus carota L.) terhadap Histopatologi Ginjal Tikus Jantan yang Diinduksi Uranium. JURNAL KEDOKTERAN YARSI. 21(1): 033-040.

Wresdiyati, T., Hartanta, A. B. \& Astawan, M. 2011. Tepung Rumput Laut (Eucheuma cottonii) Menaikkan Level Superoksida Dismutase (Sod) Ginjal Tikus Hiperkolesterolemia. Jurnal Veteriner. 12(2): 126135.

Yao, L., Li, L., Li, X. 2015. The anti-inflammatory and antifibrotic effects of coreopsis tinctoria nutt on highglucose-fat diet and streptozotocin-induced diabetic renal damage in rats. BMC Complementary and Alternative Medicine. 